\title{
Diversion Canal to Decrease Flooding (Case Study : Kebon Jati- Kalibata Segment, Ciliwung River Basin)
}

\author{
Dian Indrawati ${ }^{1, *}$, Iwan K. Hadihardaja ${ }^{2}$, M. Bagus Adityawan², Syambali F. Pahrizal ${ }^{1}$ and Fajar Taufik ${ }^{1}$ \\ ${ }^{1}$ Faculty of Engineering, Jenderal Achmad Yani University, Jalan Terusan Jenderal Sudirman, PO BOX 148, Cimahi, West Java, \\ Indonesia \\ ${ }^{2}$ Faculty of Civil and Environmental Engineering, Institut Teknologi Bandung, Jl. Ganesha No.10 Bandung 40132, West Java, Indonesia
}

\begin{abstract}
The flood in Jakarta has become a national concern in Indonesia. It is a haunting disaster, with a high probability to happen when heavy rainfalls in Jakarta and/or its upstream area. Based on data that was provided by Public Work Agency of DKI Jakarta, there are 78 vulnerable points of inundation in which, most of them are located in Ciliwung river basin, commonly in the meandering segments. One of the worst flooding occurs in Pancoran, at Kebonjati to Kalibata segment in particular. The river discharge in this segment is much higher as compared to the carrying capacity. In addition, this area has a high density of population and thus, difficult to increase the *river capacity* by enlarging the river dimension. In this research, a closed diversion canal is proposed as a solution. The effectiveness of the solution is evaluated using a numerical model, HEC-RAS 4.1. The diversion canal is designed as two culverts, with $2.0 \mathrm{~m}$ in diameter. Nevertheless, hydraulic jump may occur at the outlet of the canal due to the relatively steep slope. Therefore, the canal outlet should be designed accordingly. A Hydraulic structure such as a stilling basin can be employed to reduce the energy. The results show that the diversion canal has a good performance in decreasing water level and flood discharge in the study area. The canal has the capacity of $17,72 \mathrm{~m} 3 / \mathrm{sec}$ and succesfully decreases the water level by $4.71-5.66 \mathrm{~m}$ from flood level for $2-100$ years returned period.
\end{abstract}

\section{Introduction}

Based on data from Indonesian National Board for Disaster Management (BNPB), since 1815, flood become the most frequently disaster with $31.5 \%$ of events compare to others such as puting beliung, terorism, fire and earthquake. Specially for DKI Jakarta, during period 2011-2015, there are 98 flood events occur and most of them were happened on Ciliwung river basin and make these a national concern in Indonesia. It is a haunting disaster with a high probability hazard in every heavy rainfall occurs in DKI Jakarta area and/or its upstream of river basin.

Flood in the Ciliwung river basin had presented annually since the 1600's and in order to manage its disaster, several projects have been developing such as Amanus straits digging in North Bandengan in 1647, Bageracht and Mookervart from 1678 to 1686, and The Jakarta Flood Canal i.e. West Flood Canal (KBB) and East Flood Canal (KBT) recently.

Furthermore, a numerous sources of this disaster had been identifying, and one of them is the insufficient of the carrying capacity of the river specially in meandering segments. One of the worst flooding occurs in Pancoran area whileas in a year several spots in this area reach 2 meter-height.

Several studies related to this flood had conducted i.e Formanek [1] studied about Regional Flood Map Index for Ciliwung river flood based on FESWMS modelling, Emam [2] using HEC-HMS modelling in order to analyse land-use changes and assesment of climate in upper Ciliwung river basin, and Murniningsing [3] shows that the developing of Ciawi, Sukamahi and Katulampa weir DAM takes less significant values compared to its huge cost.

This study will analyze the effectiveness of diversion canal in order to decrease the flooding specially in Kebonjati- Kalibata segment which indicated as the source of problem in Pancoran area.

Although in some of researches show lackness of this method because of its impacts regard to sedimentation [4] and [5], the river diversion recomended for river on flattened area [6] with dense population.

\section{Literature Study}

The flow in diversion chute canal should be occoring in supercritical scheme as the result of the deployed flow on the upstream structure which is requiring quick acceleration. So in the design flow, its depth in this section should be in uniform depth. Thus, it is necessary to define which condition the flow occur along the canal. Also whileas a possibility of occuring the hydraulics jumps inside, if it is happen, the location of it should be determined. The last thing, back water curves probably occur inside and need to be analyzed along the canal [7].

\footnotetext{
* Corresponding author: author@e-mail.org
} 
In HEC-RAS [8], the diversion chute canal is modeling as the culvert condition. Which is the assumption of inlet control is that the flow passes through critical depth near the inlet and transiting to supercritical flow. If the hydraulics jump occured in this barrel, it is assumed its cause the pipe to pressuirize along the length and flow will act like an orrifice type. If this occurs, then the outlet control will become the answer.

For computing inlet control headwater with submerged inlet, the equation are :

$$
\frac{H W_{i}}{D}=c\left[\frac{Q}{A D^{0.5}}\right]^{2}+Y-0.5 S
$$

Whereas Hwi is the headwater energy depth above the invert of the culvert inlet (m), D is the interior height of the culvert barrel (m), Q is the discharge through the culvert $(\mathrm{m} 3 / \mathrm{s}), \mathrm{A}$ is the full cross sectional area of the culvert barrel (m2), $\mathrm{S}$ is the slope of culvert barrel $(\mathrm{m} / \mathrm{m})$ and $\mathrm{K}, \mathrm{M}, \mathrm{c}, \mathrm{Y}$ is equation constants, which vary depending on culvert shape and entrance conditions.

On contrary, for the outlet control flow using Bernoulli's equation in order to compute the change of energy through the barrel under outlet condition is following:

$$
Z_{3}+Y_{3}+\frac{a_{3} V_{3}^{2}}{2 g}=Z_{2}+Y_{2}+\frac{a_{2} V_{2}^{2}}{2 g}+H_{L}
$$

Where $\mathrm{Z} 3$ is the upstream invert elevation of the culvert (m), Y3 is the depth of water above the upstream culvert inlet (m), V3 is the average velocity upstream of the culvert $(\mathrm{m} 2 / \mathrm{s})$, a3 is the velocity weighting coefficient upstream of the culvert (dimensionless), $\mathrm{g}$ is the acceleration of gravity $(\mathrm{m} / \mathrm{s} 2), \mathrm{Z} 2$ is the downstream invert elevation of the culvert (m), Y2 is the depth of water above the downstream culvert inlet (m), V2 is the average velocity downstream of the culvert $(\mathrm{m} 2 / \mathrm{s})$, a2 is the velocity weighting coefficient downstream of the culvert (dimensionless) and HL is the total energy loss through the culvert (m).

The head loss is computed using the formula :

$H_{L}=h_{e n}+h_{f}+h_{e x}$

Which hen is the entrance loss (m), hf is the friction loss (m) and hex is the exit loss (m). The friction loss in the culvert is computing using Manning's formula derived as follow :

$$
h_{f}=L\left(\frac{Q n}{1.486 A R^{2 / 3}}\right)^{2}
$$

Where $\mathrm{hf}$ is the friction loss $(\mathrm{m}), \mathrm{L}$ is the culvert length (m), Q is the flow rate in the culvert $(\mathrm{m} 3 / \mathrm{s}), \mathrm{n}$ is the Manning's roughness coefficient (dimensionless), $\mathrm{A}$ is the flow area (m2) and $\mathrm{R}$ is the hydraulic radius (m).

\section{Study Site and Methodology}

\subsection{Study Site}

In order to manage the flood in Pancoran area, specially at Kebonjati to Kalibata segment, Public Work Regional Office of DKI Jakarta Province will develop the diversion canal which located on $6^{\circ} 15^{\prime} 16.99^{\prime \prime} \mathrm{S}$ $6^{\circ} 15^{\prime} 14.51^{\prime \prime S}$ and 106 $51^{\prime} 37.96 " \mathrm{E}$ - 106 $51^{\prime} 40.28^{\prime \prime} \mathrm{E}$ describes on Figure 1 below:

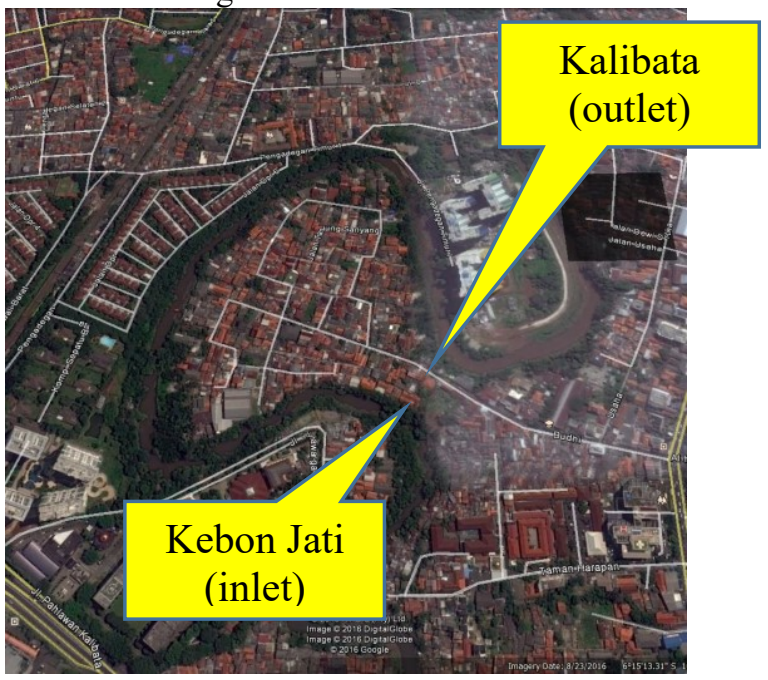

Fig. 1. Diversion Canal Location at Kebon Jati and Kalibata segment

The diversion, which located before the Manggarai water gate, is a subsystem of flood management in DKI Jakarta province and being a part of KBB.

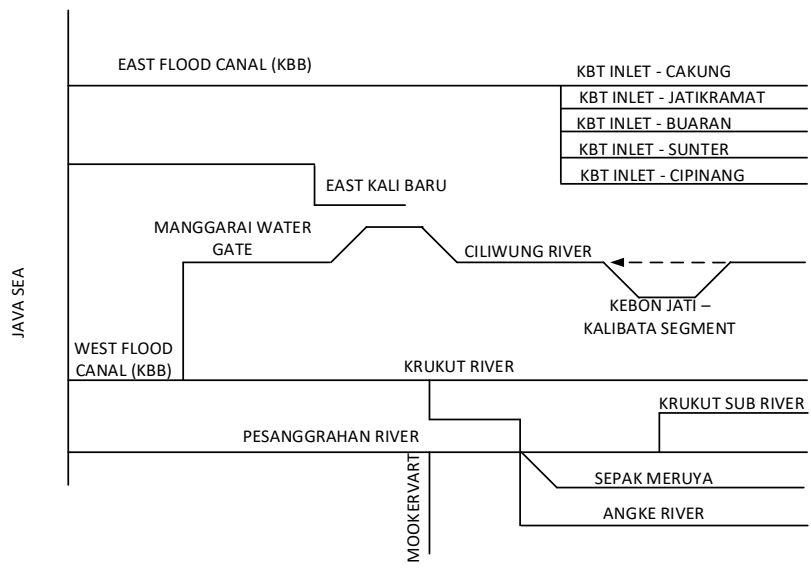

Fig. 2. Schematization of The Diversion Canal of Kebonjati Kalibata Segment on Flood Management in DKI Jakarta

\subsection{Methodology}

This study consists of hydrological and hydraulics model which are hydrological model was used to obtain flood hydrograph and hydraulics model was used to simulate the flow on the river. In order to estimate several rainfall returned period, the data was extrapolated using analysis frequency method.

For the hydraulics model, its been calibrated by comparing 2 year flood return period with capacity of river bankfull in the inlet of diversion canal. And HSS Nakayashu has closed enough values compares to Rational, Haspers and HSS Snyder-Alexjev. Moreover, the schematication of the modeling shows in Figure 3 below. 


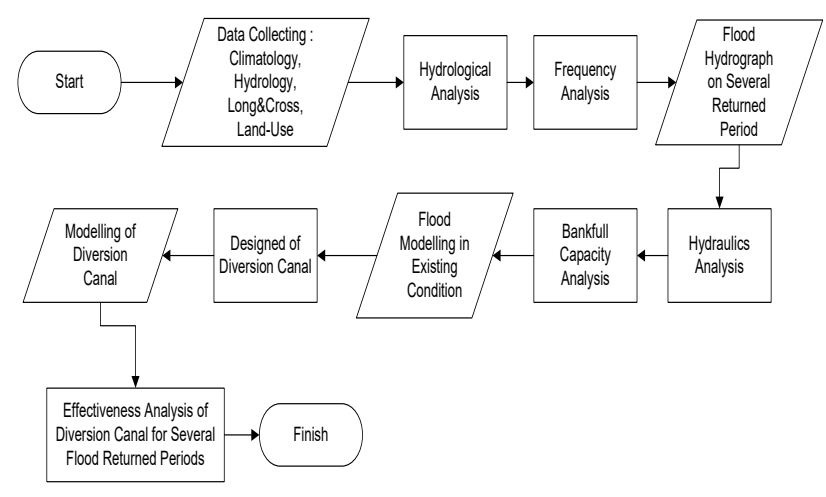

Fig. 2. Flowchart Modelling

\section{Results and Discussion}

\subsection{Boundary and Initial Condition}

The model was extended about $11.824 \mathrm{~km}$ which is divided into 210 cross sections namely by P1 to P210. From the upstream to the canal, i.e P1 to P169, has 10,271.58 meter distance for mufflling the model dissipation and analyze the backcurve current. And there are 739.35 meter along after the tunel in order to analyze the effect of canal on the downstream river which defined as P188 to P210.

For the boundary condition, the model using flood hydrograph on the upstream and water elevation in the downstream, which are the water surface will compute through existing (without canal) and design (with canal) condition, each running $2,5,10,25,50$, and 100 of the return periods of flood hydrograph.

In order to validation, the 2 years of hydraulics river model is comparing by bankfull capacity of the river to adjust the appropriate flood hydrograph for the HECRAS model as mention in the previous section.

\subsection{Diversion Canal Data and Coefficient}

The diversion canal will be held on P169 for the inlet and P188 for the outlet with 813.75 meter length. Based on the multiple choice analysis, circle culvert has been selected compare with box culvert or other shape of culvert.

The shape of the culvert itself defined by 2 circle culverts with diameter 2 meter each. The value of Manning's is 0.013 , the entrance loss coefficient is 0.5 , and the exit loss coefficient is 0.5 . The culvert also has bottom elevation on inlet +12.81 meter and outlet +9.36 meter.

\subsection{Hydrological Model}

These hydraulics model held by several hydrograph with $2,5,10,25,50$, and 100 return periods, whereas these discharges are being derivated from 11 (eleven) year of maximum daily rainfall data since 2005 until 2015 from selected stations and was transformed to the rainfall area using Polygon Thiessen which has influences area each describe on Table 1 below.
Table 1. Influence surfaces of Rainfall Station in Ciliwung River Basin

\begin{tabular}{lc}
\hline \multicolumn{1}{c}{ Stations } & $\begin{array}{c}\text { Infuence Area } \\
\left(\mathbf{( k m}^{\mathbf{2}}\right)\end{array}$ \\
\hline Bendung Gadog & 89.61 \\
Cawang & 64.10 \\
FT UI & 114.04 \\
Gunung Mas & 101.61 \\
\hline
\end{tabular}

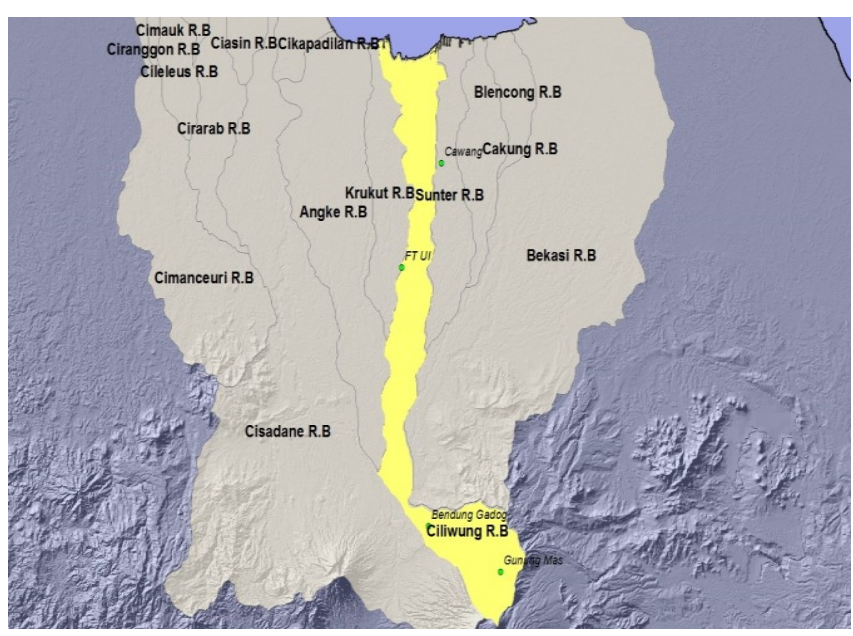

Fig. 3. Ciliwung River Basin

Table 1. Rainfall Area in Ciliwung River Basin using Polygon Thiessen

\begin{tabular}{ccccccc}
\hline No. & Year & $\begin{array}{c}\text { Bendung } \\
\text { Gadog }\end{array}$ & Cawang & $\begin{array}{c}\text { FT } \\
\text { UI }\end{array}$ & $\begin{array}{c}\text { Gunung } \\
\text { Mas }\end{array}$ & Average \\
\hline 1 & 2005 & 17.32 & 66.96 & 49.13 & 39.96 & 41.98 \\
2 & 2006 & 12.27 & 12.69 & 17.65 & 14.44 & 14.60 \\
3 & 2007 & 11.98 & 14.23 & 34.84 & 19.83 & 21.59 \\
4 & 2008 & 14.53 & 15.12 & 43.63 & 19.57 & 25.00 \\
5 & 2009 & 17.62 & 20.81 & 27.34 & 16.08 & 20.75 \\
6 & 2010 & 17.87 & 16.19 & 20.58 & 25.58 & 20.53 \\
7 & 2011 & 15.09 & 8.84 & 18.45 & 12.11 & 14.22 \\
8 & 2012 & 19.70 & 13.45 & 21.92 & 11.92 & 17.16 \\
9 & 2013 & 21.50 & 14.68 & 20.27 & 17.98 & 18.97 \\
10 & 2014 & 20.95 & 19.38 & 26.46 & 22.71 & 22.86 \\
11 & 2015 & 15.17 & 15.31 & 18.50 & 10.44 & 14.92 \\
\hline
\end{tabular}

Source : Puslitbang SDA, 2016

Based on the frequency analysis, Log Pearson III distribution was accepted with the deviation standar value is 0.13 , the skewness coefficient $(\mathrm{Cs})$ is 1.25 and the Kurtosis coefficient $(\mathrm{Ck})$ is 2.44. Further, fit tests using Chi square and Smirnov Kolmogorov that show the acceptance of Log Pearson III distribution.

The values of calculated Chi-Square is 3.09, The Critical Chi-Square value is 5.99 , the freedom of degree is 2.00 and the significant degree is 0.05 . On contrary, for the smirnov kolmogorov test results the $\mathrm{D}$ max value is 0.428 , the significant degree is 0.050 and the Critical D is 0.396 .

Because of the lack of hourly rainfall data in its location, the rainfall pattern assumed by using average pattern rainfall in Indonesia specially in Jawa island with distribution $55 \%, 14 \%, 10 \%, 8 \%, 7 \%$ and $6 \%$ for six hours of rainfall. Wheras calculation of the returned period of rainfall is : 
Table 2. Rainfall Distribution in Ciliwung River Basin

\begin{tabular}{|c|c|c|c|c|c|c|c|c|c|}
\hline \multicolumn{2}{|c|}{ Parameter } & \multicolumn{8}{|c|}{ Returned Period } \\
\hline & & 2 & 5 & 10 & 25 & 50 & 100 & 200 & 1000 \\
\hline \multicolumn{2}{|c|}{ Rainfall (R) } & 21.45 & 25.21 & 30.47 & 38.49 & 45.59 & 53.75 & 63.17 & 91.18 \\
\hline \multicolumn{2}{|c|}{$\begin{array}{l}\text { Netto Rainfall } \\
\text { [mm/day] }\end{array}$} & 10.61 & 12.47 & 15.07 & 19.04 & 22.55 & 26.58 & 31.24 & 45.10 \\
\hline Hour & Distribution & \multicolumn{8}{|c|}{ Hourly Rainfall [mm/hour] } \\
\hline 1 & $55 \%$ & 5.84 & 6.86 & 8.29 & 10.47 & 12.40 & 14.62 & 17.18 & 24.80 \\
\hline 2 & $14 \%$ & 1.49 & 1.75 & 2.11 & 2.67 & 3.16 & 3.72 & 4.37 & 6.31 \\
\hline 3 & $10 \%$ & 1.06 & 1.25 & 1.51 & 1.90 & 2.25 & 2.66 & 3.12 & 4.51 \\
\hline 4 & $8 \%$ & 0.85 & 1.00 & 1.21 & 1.52 & 1.80 & 2.13 & 2.50 & 3.61 \\
\hline 5 & $7 \%$ & 0.74 & 0.87 & 1.05 & 1.33 & 1.58 & 1.86 & 2.19 & 3.16 \\
\hline 6 & $6 \%$ & 0.64 & 0.75 & 0.90 & 1.14 & 1.35 & 1.60 & 1.87 & 2.71 \\
\hline
\end{tabular}

Furthermore, the flood discharge calculated by using UH Nakayashu based on fittest analysis. The results of Nakayashu unit hydrograph are shown in Table 3.

Table 3. Figure 5 Flood Discharge using UH Nakayashu

\begin{tabular}{lc}
\hline $\begin{array}{l}\text { Returned } \\
\text { Periods }\end{array}$ & $\begin{array}{l}\text { Discharge } \\
{\left[\mathrm{m}^{3} / \mathrm{sec}\right]}\end{array}$ \\
\hline 2 & 55.44 \\
5 & 63.50 \\
10 & 78.40 \\
25 & 102.59 \\
50 & 125.17 \\
100 & 152.27 \\
200 & 184.89 \\
1000 & 290.36 \\
\hline
\end{tabular}

\subsection{Modelling of Existing Condition}

Based on its contour, Ciliwung river has steep and tight topography in the upstream and become more mild and widen follows the downstream. Because of the lack of observation discharge data, the result from hydrology modelling is being compared with analysis of bankfull capacity at P146. The modelling results for two year return period of rainfall will lead $102.59 \mathrm{~m} 3 / \mathrm{s}$ of discharge with $5.172 \mathrm{~m}$ of water elevation and the rating curve resulted $103.64 \mathrm{~m} 3 / \mathrm{s}$ of discharge with $5.172 \mathrm{~m}$ of the water elevation, respectively.

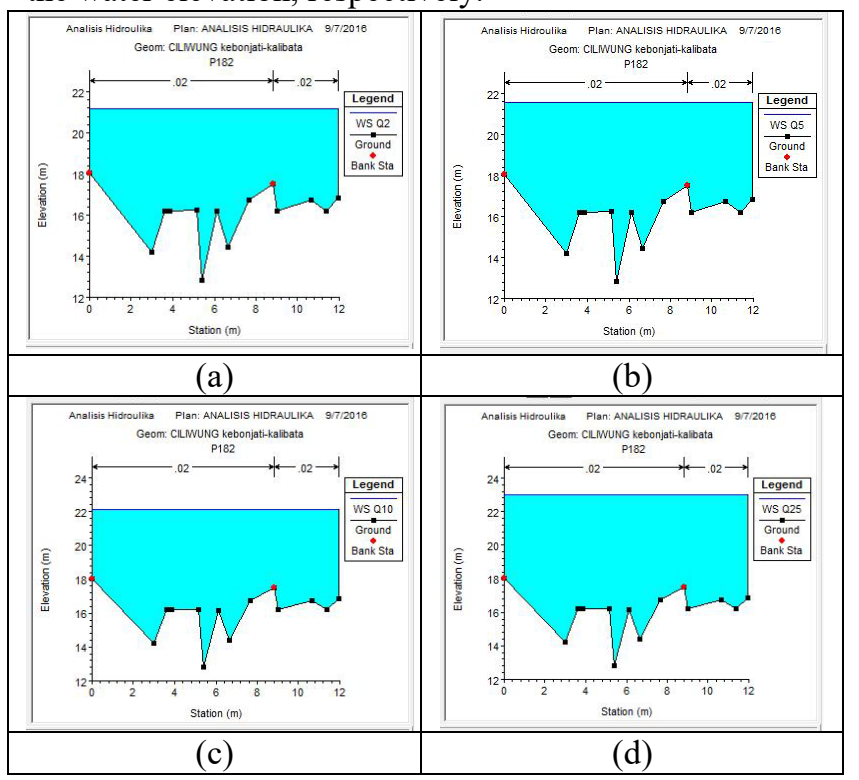

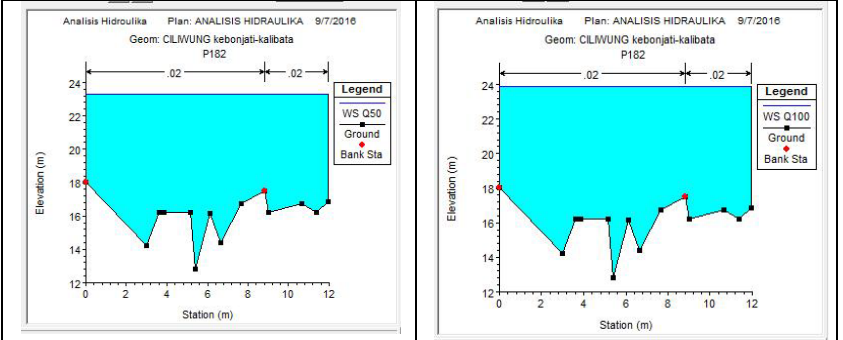

Fig. 4. Existing Flood Modelling using several returned periods. (a) 2 year; (b) 5 year; (c) 10 year; (d) 25 year; (e) 50 year; and (f) 100 year

Figure 5 shows the overtopping of Ciliwung river specially in the inlet location for all years of return periods. The discharge of each is $55.44 \mathrm{~m} 3 / \mathrm{s}, 63.50$ $\mathrm{m} 3 / \mathrm{s}, 78.40 \mathrm{~m} 3 / \mathrm{s}, 102.59 \mathrm{~m} 3 / \mathrm{s}, 125.17 \mathrm{~m} 3 / \mathrm{s}$ and 152.27 $\mathrm{m} 3 / \mathrm{s}$ for $2,5,10,25,50$ and 100 year, respectively.

\subsection{Modelling of Diversion Canal}

Based on model, the diversion canal has super critical flow with Froude number 1.418 inside and has pressure difference $43654.50 \mathrm{~kg} / \mathrm{m} . \mathrm{s} 2$. This modeling using two condition in order to calculate head loss i.e normal and flooding. Total head loss in flood condition is 0.402 meter and on normal condition and 0.492 meter on flooding condition which the water temperature is $30^{\circ} \mathrm{C}$. The diversion canal obviously making a significant impact for decreasing water elevation in KebonjatiKalibata segment and clearly reducing the floodi in Ciliwung river basin. With fully submerged flow, the diversion canal could carried $35.44 \mathrm{~m} 3 / \mathrm{s}$ discharge from inlet to outlet and shortcut the way along meandering segment in Ciliwung river as shown on Table 4.

Table 4. Recapitulation of Influence of the Diversion Canal to The Water Level Elevation on Ciliwung River

\begin{tabular}{|c|c|c|c|c|c|c|}
\hline \multirow{2}{*}{$\begin{array}{l}\text { Return } \\
\text { Periode }\end{array}$} & \multirow{2}{*}{$\begin{array}{c}\text { Flood } \\
\text { Discharge } \\
{\left[\mathrm{m}^{3} / \mathrm{s}\right]}\end{array}$} & \multirow{2}{*}{$\begin{array}{c}\text { Diversion } \\
\text { Canal } \\
\text { Discharge } \\
{\left[\mathrm{m}^{3} / \mathbf{s}\right]} \\
\end{array}$} & \multirow{2}{*}{$\begin{array}{c}\text { Total } \\
\text { Discharge } \\
{\left[\mathrm{m}^{3} / \mathbf{s}\right]}\end{array}$} & \multicolumn{2}{|c|}{ Water Elevation [m] } & \multirow[t]{2}{*}{ Not } \\
\hline & & & & $\begin{array}{c}\text { Before } \\
\text { Diversion } \\
\text { Canal } \\
\end{array}$ & $\begin{array}{c}\text { After } \\
\text { Diversion } \\
\text { Canal } \\
\end{array}$ & \\
\hline 2 & 55.44 & 35.44 & 20.00 & 21.17 & 16.46 & $\begin{array}{l}\text { Down } \\
4.71 \mathrm{~m} \\
\end{array}$ \\
\hline 5 & 63.50 & 35.44 & 28.06 & 21.54 & 16.76 & $\begin{array}{l}\text { Down } \\
4.78 \mathrm{~m}\end{array}$ \\
\hline 10 & 78.40 & 35.44 & 42.96 & 22.16 & 17.08 & $\begin{array}{l}\text { Down } \\
5.08 \mathrm{~m}\end{array}$ \\
\hline 25 & 102.59 & 35.44 & 67.15 & 23.02 & 17.52 & $\begin{array}{l}\text { Down } \\
5.50 \mathrm{~m}\end{array}$ \\
\hline 50 & 125.17 & 35.44 & 89.73 & 23.33 & 17.82 & $\begin{array}{l}\text { Down } \\
5.51 \mathrm{~m}\end{array}$ \\
\hline 100 & 152.27 & 35.44 & 116.83 & 23.87 & 18.21 & $\begin{array}{l}\text { Down } \\
5.66 \mathrm{~m}\end{array}$ \\
\hline
\end{tabular}

\section{Conclusions}

Results of the simulation of its diversion canal shows on Figure 7 below, whereas on every returned period, water level becomes decreased significantly from $4.71-5.66$ meter. Its means the diversion canal achieved $22.25 \%$ $23.71 \%$ decrease of flood in this segment. 


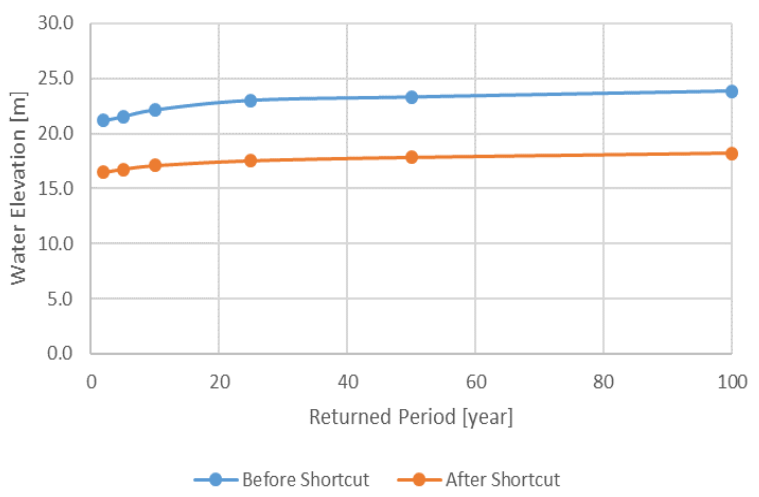

Fig. 5. Water Elevation Before and After Diversion Canal Development

Eventhough the diversion canal obviously making a significant impact for reducing the flood in meandering segment of Kebonjati-Kalibata area. But there are some circumtances related to supercritical flow along the canal and hydraulic jump on the canal outlet. They will make a scouring and sedimentation problem in the canal downstream and these complex interacting system will influences the river morphology.

Further, research about sedimentation need to be held seriously and developing of stilling basin on the canal outlet is necessary in order to muffle the hydraulic jump.

This study was supported by Public Work Regional Office of DKI Jakarta Province for project title as "Planning and Detail Designed of Management Ciliwung River from Manggarai Watergate to its Upstream" specially for the topography data and particularly indebted to the UNJANI Competitive Research 2017 for some part of financial sharing and support.

\section{References}

1. Formanek. Adam, Rasmiaditia Silasari, M. Syahril B.K, Kardhana.. H, J. Eng. Technol. Sci. E 45(3), 307-325 (2013)

2. Emam A.R, Mishra B.K, Kumar P, Masago Y, Fukushi K, Water. J.E 8(12), 559 (2016)

3. Murniningsih S, Anggraheni E, Int. Journal of Environment, Chemical, Ecological, Geological and Geophysical Eng. J.E 10, 2 (2016)

4. Sharp A.J, Heath. R.E, Clifton N.D, Journal of Water Res and Protection, E 5, 16-29 (2013)

5. Bowles D.S, Grant J.L, Humphries W.E, O'hayre A.P, WR Bulletin EWRA, E. 21(6), 995-1003 (1985)

6. BUREC, Design of Small Dams (WR Tech Publication, Denver, 1987)

7. Silva S.A.O, River Diversion Structures: Conception, Design and Adaption to Definitive Structures (Instituto Superior Tecnico)

8. Brunner G.W, HEC-RAS River Analysis System Hydraulic Reference Manual Version 4.1 (U.S. Army Corps of Engineers: Davis, CA, 2010) 